\title{
THE JOURNAL OF
}

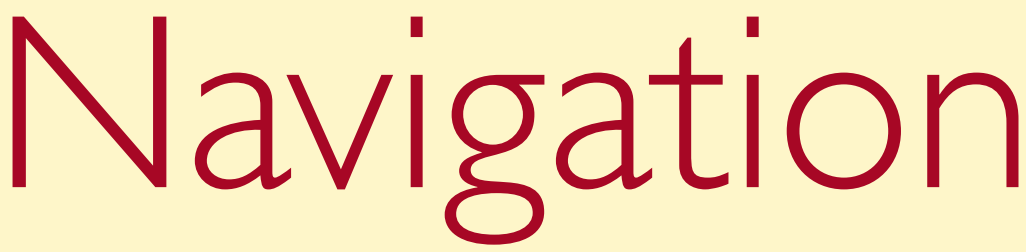

VOLUME 70 NUMBER 3 MAY 2017

$\$$ Royal Institute of Navigation Science Technology Practice 


\section{THE ROYAL INSTITUTE OF NAVIGATION}

Science Technology Practice

\section{THE JOURNAL OF NAVIGATION \\ Editor-in-Chief Nick Randall MSc FRIN \\ Editor Tony Fyler}

Prof. Ruizhi Chen PhD

Texas A\&M University, Corpus Christi, USA

Dr. Ashim Debnath PhD

Victoria University, Australia

Dr. Ramsey Faragher CPhys FRIN MION

University of Cambridge, UK

Dr. Shaojun Feng PhD FRIN

Imperial College London, UK

Assoc. Prof. Renato Filjar PhD FRIN

University of Rijeka, Croatia

Dr. Paul D Groves DPhil CPhys FRIN

University College London, UK

Prof. Peter J. Hore MA DPhil

University of Oxford, UK

Prof. Shuanggen Jin PhD FIAG

Shanghai Astronomical Observatory, China

Dr. Olivier Julien

ENAC, France
Prof. Izzet Kale

Associate Editors

University of Westminster, UK

Dr. Lawrence Lau PhD FRICS FRIN

University of Nottingham Ningbo China, China

Assoc. Prof. Simona Lohan PhD

Tampere University of Technology, Finland

Prof. Margareta Lützhöft PhD FNI MRIN

Australian Maritime College, University of Tasmania,

Australia

Dr. Gene McCall AFRIN

Los Alamos, USA

Dr. Xiaolin Meng FRIN

University of Nottingham, UK

Dr. Erik Styhr Petersen PhD MNI MSNAME

Denmark

Dr. James Pinchin PhD AFRIN

University of Nottingham, UK
Prof. Roberto Sabatini PhD DEng FRIN

RMIT University, Australia

Dr. Wolfgang Schuster FRIN

Atkins, UK

Dr. Rafal Szlapczynski PhD

Gdansk University of Technology, Poland

Prof. Peter J.G. Teunissen AFRIN

Curtin University, Australia and Delft University of

Technology, The Netherlands

Assoc. Prof. Jinling Wang FRIN FIAG

University of New SouthWales, Australia

Dr. Nick Ward PhD CEng FRIN

General Lighthouse Authority, UK

Prof. Adam Weintrit FRIN FNI

Gdynia Maritime University, Poland

Prof. Yuanxin Wu PhD

Shanghai Jiao Tong University, China

Editorial Board. The Editorial Board (for administrative matters) consists of the members of the Royal Institute of Navigation's Technical Committee.

Editorial Advisory Board. The Chairman of the Editorial Advisory Board (for academic matters) is the Royal Institute of Navigation Director (Capt P. C. Chapman-Andrews, LVO MBE), the Secretary is the Journal Editor-in-Chief (Nick Randall MSc FRIN) and it consists of the following members:

\section{Name}

Prof. Susanne Akesson FRIN

Prof. Craig Allen FRIN

Prof. Vidal Ashkenazi FRIN

Prof. Victoria Braithwaite FRIN

Prof. Alan Dodson FRIN

Dr. Alexander Dunaev

Dr. Ahmed El-Mowafy

Prof. Ahmed El-Rabbany

Prof. Naser El-Sheimy

A/Prof. Renato Filjar FRIN

Dr. Marianne George

Prof. Dorota Grejner-Brzezinska

Dr. Chris Hegarty

Prof. Dah-Jing Jwo

Prof. Izzet Kale

Dr. Allison Kealy

Prof. Changdon Kee

Prof. Joseph Kirschvink AFRIN

Prof. Dr. Serdjo Kos FRIN

Prof. Tomislav Kos FRIN

Prof. Richard Langley FRIN

Prof. David Last FRIN

Prof. Jingnan Liu

Dr. Sherman Lo

Prof. Ken Lohmann FRIN

Dr. Gene McCall AFRIN

Dr. Xiaolin Meng FRIN

\section{(Affiliation, Region)}

Lund, Sweden

Washington, USA

NSL, UK

Penn State, USA

Nottingham, UK

JSC 'RSS', Russia

Curtin, Australia

Ryerson, Canada

Calgary, Canada

Rijeka, Croatia

Pacific Traditions, USA

Ohio State, USA

MITRE, USA

Nat. Taiwan Ocean, Taiwan

Westminster, UK

Melbourne, Australia

Seoul, S. Korea

Caltech, USA

Rijeka, Croatia

Zagreb, Croatia

New Brunswick, Canada

Consultant, UK

Wuhan, China

Stanford, USA

North Carolina, USA

Los Alamos, USA

Nottingham, UK

\section{Name}

Prof. Stella Mills AFRIN

Prof. Terry Moore FRIN

Prof. Paul Newman

Prof. Andy Norris FRIN

Prof. Washington Ochieng FRIN

Prof. Patrick Oonincx

Prof. Maciej Pawlowski

Prof. Malek Pourzanjani FRIN

Prof. Thorsten Ritz FRIN

Dr. Wolfgang Schuster FRIN

Prof. Sir Martin Sweeting

Prof. Peter Teunissen AFRIN

Prof. Gert Trommer FRIN

Dr. Martin Unwin FRIN

Prof. Peter Vörsmann

Prof. Charlie Walcott FRIN

Prof. Mike Walker FRIN

A/Prof. Jinling Wang FRIN

Prof. Adam Weintrit FRIN

Prof. Jinxian Weng

Prof. Roswitha Wiltschko FRIN

Prof. Wolfgang Wiltschko FRIN

Prof. Michael Winklhofer

Prof. XuHaiYang

Prof. Yuanxi Yang

Prof. Marek Ziebart

Prof. Nesreen Ziedan AFRIN
(Affiliation, Region)

Staffordshire, UK

Nottingham, UK

Oxford, UK

Consultant, UK

Imperial College, UK

Defence, Netherlands

Gdansk, Poland

Raffles, Malaysia

California, USA

Imperial College, UK

SSTL, UK

Curtin, Australia

Karlsruhe, Germany

SSTL, UK

Braunschweig, Germany

Cornell, USA

Auckland, New Zealand

Sydney, Australia

Gdynia, Poland

Beihang, China

Frankfurt, Germany

Frankfurt, Germany

Munich, Germany

Academy of Sciences, China

CNAGA, China

UCL, UK

Zagazig, Egypt

The Journal Journal is published six times a year by Cambridge University Press. It contains original papers contributing to the science of navigation, including those presented at the meetings of the Institute. Papers should be submitted via the link http://mc.manuscriptcentral. com/ nav. The Editor-in-Chief may be contacted via e-mail at journal@rin.org.uk. The current 'Instructions for Contributors' are available online or by e-mail. The views expressed in the Journal are not necessarily those of the Institute, or of any organisation or department to which the authors may belong. Crown Copyright may be reserved. Any facts stated or opinions expressed in this Journal are the sole responsibility of the contributors. Neither the Royal Institute of Navigation, the Editor nor the Publishers can be held responsible for any injury or loss sustained in reliance thereon.

This journal is included in the Cambridge Journals Online service (http://journals. cambridge. org). For further information on other Press titles access http:/ / www.cambridge.org

The address of the Institute is The Royal Institute of Navigation, at The Royal Geographical Society, 1 Kensington Gore, London SW7 2AT (Telephone: 02075913130 Fax: 0207591 3131), website (www.rin.org.uk) e-mail (editor@rin.org.uk).

This journal issue has been printed on FSC-certified paper and cover board. FSC is an independent, non-governmental, not-for-profit

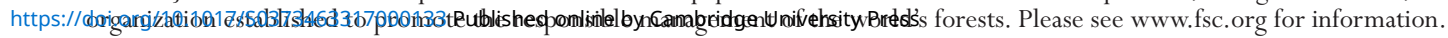

